\title{
The effectiveness of Online Virtual Tours in Developing EFL Speaking Skills among Secondary School Students
}

\author{
A research
}

Presented by:

Sherihan Mostafa Eissa

English language lecturer

Abstract:

Speaking skills are of great importance for both learners and educators. In the recent few years more attention is being given to improving the oral communication skills. In this research, the researcher aims to investigate how far the use of online video tours to the most famous touristic cities around the world help to improve the speaking skills of secondary school students. The proposed program included six speaking units; each lesson presented an authentic online tour video in a different city and its sights. The research design is quasi-experimental. The participants are secondary school students from an official language school in Egypt. The results of the post speaking test indicated a significant improvement in the speaking skills. The study showed that there were statistically significant differences between the pre-test and the post-test in the experimental group in favor of the post test. Consequently, it was concluded that the online tours program helped in fostering the secondary school students' speaking skills.

\section{Keywords:}

Speaking, videos, communication skills, accuracy, fluency, online trips. 
الملخص:

مهار ات التحدث هى من أهم مهار ات اللغة لكل من المعلمين والطلاب على حد سواء

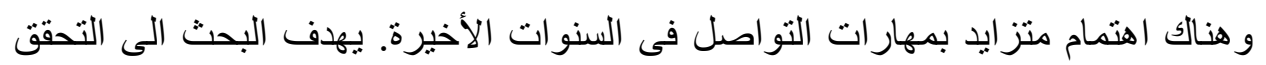

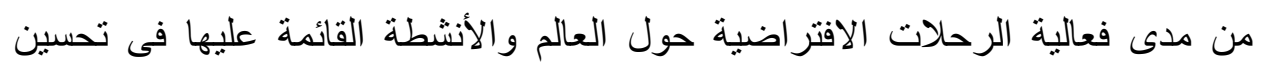
مهارات التحدث لطلاب المرحلة الثانوية. يتكون البرنامج من ستة وحدات كل منهم يحتوى على رحلة افتر اضية الى بلد او مدينة حول العالم ومجمو عة من الأنثطة التفاعلية.

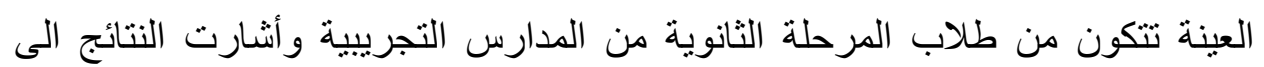
تحسن فى مهارات التحدث لاى الطلاب مما بدل على فعالية استخدام الرحلات الافتر اضية والأنشطة القائمة عليها فى تطوير مهار ات التحدث.

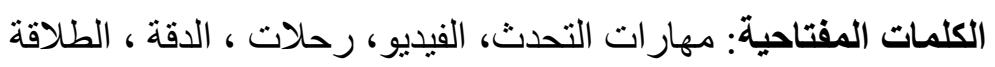




\title{
The effectiveness of Online Virtual Tours in Developing EFL Speaking Skills among Secondary School Students
}

\author{
A research \\ Presented by: \\ Sherihan Mostafa Eissa \\ English language lecturer
}

\section{Introduction:}

Speaking skills are associated with language mastery, fluency, accurate and effective communication. Through oral communication skills, learners begin to acquire new language features and then apply it to different interactive situations. Generally speaking, knowing a language is usually defined by the ability to speak it.

Rocio (2011) asserted that listening and speaking skills are related, and it is really important to put them into practice together and integrate them with the remaining language skills to get a perfect acquisition of second/ foreign language. He adds that students need to know how to communicate using English because if they travel abroad, they are going to communicate mostly through listening and speaking, not reading or writing.

With the spread of technology and digital applications, a variety of listening materials emerge as a helpful educational resource. Alizadeh (2019) emphasized that virtual reality has become a buzzword among teachers over the past few years due to its availability and cheapness. He goes on to say that any teacher can lead his students in an online tour, guiding, monitoring them and calling their attention to specific points of interest. Al-Ghamdi (2019) mentions that in the recent literature on the adoption of new technology in EFL classrooms, much attention is paid to the application of virtual reality. He adds that if audiobooks, video materials and presentations among other tools are viewed among common application of technology in language-learning environment, the utilization of blogs, websites, social media, 
simulations, videogames, online platforms and other similar media are related to Computer- Assisted Language Learning (CALL). Consequently, CALL is applied to provide students with authentic language to improve students' pronunciation and communicative skills.

These days teachers want to continue delivering the same quality education during lockdown as they were in the classroom, but are wondering how. Thankfully, as the rest of the world adapts, some new, innovative, and engaging options are emerging. There are learning platforms with educational games (e.g. education.com) and interactive stories and virtual museum tours. (https://oupeltglobalblog.com/2020/05/21/students-virtual-fieldtrip/)

Similarly, teachers can apply varied types of online tours; they can take their students to different landscapes, wonders, sights, natural habitats, historical places, hotels...etc. The availability of this treasure of online resources makes it so simple and easy for English teachers to benefit from them. According to Yuskelir and Kumur (2017), the increase of communicative language theories, online videos and technology-based resources made a great tendency towards the use of technology and its integration into curriculum in the last decades. They go on to mention that using videos in one of the most motivating tools in teaching English and that the increasing emphasis on communicative techniques and the use of video in ELT classrooms have gained the attention of researchers recently. Consequently, this research aims to investigate how far it is beneficial to use online, virtual tours for improving the speaking ability among secondary school students.

\section{Statement of the Problem}

Based on the pilot study conducted by the researcher, there are some existing problems that students encounter in speaking skills and there is a lack of interesting and authentic listening and speaking material and communicative activities that can possibly make students able to communicate in English. As a result, the 
researcher proposes an online tours program based to promote secondary school students' speaking skills.

\section{Hypotheses of the research:}

1- $\quad$ No statistically significant mean difference will be found at 0.05 level between the mean scores of the experimental group on the total speaking skill pre- and post- test.

2- $\quad$ No statistically significant mean difference will be found at 0.05 level between the mean scores of the experimental group on the speaking pronunciation pre- and post- test.

3- No statistically significant mean difference will be found at 0.05 level between the mean scores of the experimental group on the speaking vocabulary pre- and post- test.

4- No statistically significant mean difference will be found at 0.05 level between the mean scores of the experimental group on the speaking grammar pre- and post- test.

5- No statistically significant mean difference will be found at 0.05 level between the mean scores of the experimental group on the total speaking accuracy pre- and post- test.

6- No statistically significant mean difference will be found at 0.05 level between the mean scores of the experimental group on the speaking fluency pre- and post- test.

\section{Context of the problem:}

In the governmental language schools, there is usually less attention to the oral communicative skills. Teachers pay more attention to reading and writing. Students do not have enough time to practice listening and speaking as teachers skip the speaking and listening activities which leads to little exposure to authentic language. Consequently, students in the governmental language schools usually have difficulties in speaking English accurately and fluently. 


\section{Review of literature:}

\section{Speaking Skills:}

Speaking is one of the most essential language skills. Derakhshan et al. (2016) confirmed that speaking is a productive skill that consists of two major components: accuracy and fluency. Accuracy means the correct use of grammar, vocabulary and pronunciation, whereas fluency means the ability to continue speaking spontaneously and to produce larger segments of speech without hesitations or pauses.

\section{Importance of speaking skills:}

Speaking skills are necessary for interactions in the EFL/ESL contexts and for communication with the Englishspeaking countries. As a result, teachers find it increasingly important to do whatever possible to develop the communication skills of their students.

Richards (2008) stresses the fact that that the proficiency of speaking skills in English is a priority for many second or foreign language learners. Moreover, learners often evaluate their success in language learning as well as the effectiveness of their English course on the basis of how far they feel they have achieved mastery in their spoken language. Lazarton (in Celce-Murcia, 2001, p: 103) states that for many people, the ability to speak a language is synonymous with knowing that language since speaking is the most basic means of language use.

\section{Status of speaking skills in EFL/ESL classes:}

Richards (2008) confirmed that research has also shed considerable light on the complexity of the speaking skill in either a first or second language. However, speaking in a foreign language has generally been considered the most demanding of the four skills. Perhaps the most difficult aspect of spoken English is that it is almost always accomplished through interaction with other speakers. This means that a number of demands are all in place at once: monitoring and understanding the other speaker(s), thinking about one's own contribution, producing that contribution, 
monitoring its effect, and so on. Rocio (2011) states that sometimes there may be some disappointment among EFL learners as they have spent a lot of time studying and practising English, but still they cannot speak it fluently.

\section{Components of speaking effectiveness:}

There are four major components of communicative competence according to Canale and Swain's adaptation of Hymes' communicative competence theory (1971). Lazarton ( in CelceMurcia, 2001) lists them as follows:

1- Grammatical competence: this includes rules of phonology, orthography, vocabulary, word formation, and sentence formation.

2- Discourse competence: this includes rules of both cohesion (how sentence elements are tied together via reference, repetition, synonymy...etc) and coherence (how texts are constructed).

3- Sociolinguistic competence: this includes rules for expression and understanding of appropriate social meanings and grammatical forms in different contexts.

4- Strategic competence: this includes a repertoire of compensatory strategies that help with a variety of communication difficulties.

\section{Factors that affect students' speaking proficiency:}

There are some elements that determine the speaking proficiency level of EFL/ESL learners. Derakhshan et al. (2016) points out that the level of learners' speaking proficiency is decided by the following factors:

1- Cognitive factors: Speaking involves cognitive processes such as conceptualization, formulation and articulation.

2- Linguistic factors: effective communication needs good use of linguistic features such as grammar, vocabulary and pronunciation.

3- Affective factors: affective factors such as anxiety, motivation and self-esteem affect learners' speaking proficiency to a great extent. 


\section{Kinds of Speaking Performance:}

Among the crucial roles of foreign language teachers is to help students communicate effectively to achieve different language functions. Derakhshan et al. (2016) asserts that teachers can make use of some types of speaking performance to help students develop their speaking skills:

A- Imitation: students pay attention to certain vowels, consonants, intonation etc., then, they imitate correctly.

B- Responsive: it refers to students' responses and interactions with others.

C- Intensive: It means any planned speaking performance that aims at practicing some phonological or grammatical features of language.

D- Transactional dialogue: It is used to send a message or convey some facts or information.

E- Interpersonal dialogue: It is used to maintain social relationships not for transmission of facts or information.

\section{Teaching speaking:}

Kasap (2005) mentioned that Communicative Language Teaching (CLT) appeared in the 1960s as a reaction to many methodological inadequacies. CLT considers language a means for meaningful communication, so in this approach, for instance, comprehensible pronunciation rather than native-like pronunciation was the goal. CLT gave equal importance to the functional as well as the structural aspects of language (Littlewood, 1983; Nunan, 1987). In CLT, meaningful and communicative activities are used to provide learners with the required skills to use authentic language. "Using language to learn it" rather than "Learning language to use it" became the slogan of CLT (Widdowson, 1978).

Helping students to speak fluently and accurately was the important language goal in meaningful contexts in the CLT approach. CLT had many methodological offspring which tried to shape the principles of CLT into more specific teaching practices. Thus, content-based instruction and task-based instruction all are 
based on the idea that language is learned via using it communicatively, with processing in language of equal importance to producing it.

\section{Speaking Activities:}

Developing oral skills in ESL/EFL contexts can be achieved through different ways. Lazarton (in Celce-Murcia, 2001, p: 106) discusses the main types of speaking activities as follows:

- Discussions: They are often the most commonly used activity in the oral skills class. Teachers should take care in organizing and setting up a discussion activity. Students need to be familiar with the topic, prepared and be clear about what they are to discuss, why they are discussing it, and what outcome is expected.

- Speeches: Topics for speeches vary based on the level of the student and the focus of the class; however, students should be given some leeway in selecting the topic and content of their talks. In other words, the teacher can provide the structure for the speech and its time limits while the students select the content.

- Role Plays: It is convenient for practicing the sociocultural variations in speech acts. Depending on student level, role plays can be performed from prepared scripts, created from a set of prompts and expressions or written using and consolidating knowledge acquired from instruction or discussions.

- Conversations: One of the most recent trends in oral skills teaching is the emphasis on having students analyze and evaluate the language that they or others produce. In other words, it is not suitable to have students produce lots of language; they should become more aware of the many aspects of language in order to become competent speakers and interlocutors in English. One speaking activity which is particularly convenient to this kind of analysis is conversation, the most basic form of oral communication. 


\section{Evaluating performance on speaking activities:}

Mead and Rubin (1985) emphasized that there are two ways for assessing speaking skills. As for the observational approach, the student's behavior is observed and assessed unobtrusively. In the structured approach, the student is asked to perform one or more specific oral communication activities. His or her performance on the task is then evaluated. The activity/ task can be applied or performed in a one-on-one setting with the test administrator and one student or in a group or class setting. In either setting, students should feel that they are communicating meaningful output to a real audience. Tasks should focus on topics that all students can easily discuss, or, if they do not include such a familiar topic, students should be given an opportunity to collect information on the new topic.

Rocio (2011) indicated that the informal assessment of speaking activities is necessary, because there are some difficulties related to administering formal oral tests. Generally, informal assessment can mostly take the form of student observation and monitoring of activities.

Both observational and structured approaches use a different rubrics or rating systems. A holistic rating gives a general impression of the student's performance. A primary trait score evaluates the student's ability to achieve a specific communication purpose for example, to persuade the listener to adopt a specific point of view. Analytic scales capture the student's performance on different aspects of communication, for example. delivery, organization, content, and language. Rating systems may describe varying degrees of proficiency along a scale or may indicate whether the trait is present or absent.

One of the major criteria of any rating system is rater objectivity: Is the rater applying the scoring criteria accurately and consistently to all students across time? The reliability of raters should be established during their training and checked during administration or scoring of the assessment. If ratings are made on

Egyptian Journal of Educational Sciences (118) Issue 1 (Part One) 2021 
the spot, two rates will be required for some administrations. If ratings are recorded for later scoring, double scoring will often be needed.

Lazarton ( in Celce-Murcia, 2001) stresses that the speaking skills teacher may be required to make decisions about two kinds of oral assessment: evaluating classroom performance in the speaking classroom activities or preparing students to take large scale oral examinations.

Any speaking activity should have the following assessment criteria: (Richards, 2008)

1- Clarity of presentation: This means the extent to which the speaker organizes information in an easily comprehensible order.

2- Use of discourse markers, repetition, and stress to emphasize important points and to make the lecture structure more salient to the listeners.

3- Delivery: The speaker's voice and language should be clear and comprehensible. In addition, the speech rate should be appropriate.

4- Language: The speaker's language should be accurate and he/she should use a wide range of vocabulary.

5- Content: The content should be relevant to the activity.

\section{Online videos:}

Walkins and Watkins (2011) stress that youtube and other online video resources are most immediately observed through sight and sound, motivated teachers can find creative ways to apply them in ELT conversational classes. They go on to list a few possible activities for EFL teachers:

-Conversation analysis: In this activity, students view teacherselected clips that demonstrate effective conversational techniques that reinforce material taught in classroom.

-Famous movie scene reenactment: In this activity, students can select a famous scene or master scene from a movie, and then reenact it, either as a dramatic presentation in front of the class or in a video clip of their own.

-Vlogging: This is a regular speaking activity that can be performed by any student. This activity allows for regular and extended 
speaking practice. Vlogging is short for video logging. In essence, a vlog is an online diary in video form.

- Movie trailer voiceover: In this activity, students can select any two-minute movie preview from the youtube, and then students transcribe the audio in the preview.

\section{Online and virtual videos in TEFL contexts:}

The use of online videos is generally beneficial in language teaching, while the use of virtual reality has an added value to English Language Teaching. For Al-Ghamdi (2019, p: 28), the reference to virtual reality is often discussed as important to help learners concentrate on culturally specific or authentic tasks and receive a unique cultural experience while being involved in the target language immersive context. These online or digital contexts are characterized by high level of visual appeal for English learners to provoke their interest in language -oriented activities and they provide young persons with a variety of interactive tools to use English. Additionally, much attention is also paid to the emotional aspect of learning English with the help of specific features of virtual reality. According to the results of some studies, some students prefer this innovative approach to developing their language skills because of the positive associations with activities and the absence of boring tasks and the overall dynamic setting connected with this interesting content.

\section{Using Videos in classrooms:}

Videos are available technological tools that can be used effectively to enrich language classrooms, especially in teaching the oral communication skills.

Here are five major advantages that teachers can acquire via using videos in the classroom. (https://filmora.wondershare.com/)

1. Videos motivate students: Videos can be one of the best tools that you can use for presenting new knowledge. They also increase interaction and entice students to learn new information. Videos can engage students in an immersive learning experience. 
2. Videos stimulate activities: When using videos, teachers can produce a good start for the classroom activities.

3. Videos present interesting information: Videos are always full of information. Videos also present the information in an interesting way.

4. Videos bring the outside world into classroom: videos make it very simple for teachers to create authentic and fun lessons that will engage students in real life situations.

5. Videos facilitate understanding: Research has proved that using videos for learning makes it much easier for students to understand different topics and ideas.

\section{Advantages of using videos:}

According to Woolfitt (2015), using videos offer following advantages :

1. More availability makes content accessible to a various student population

2. Cost effective, time efficient and enjoyable for students

3. Utilizing in-class time for interactive learning

4. Videos are tools of differentiation: utilizing videos in the classroom plays a great role for supporting the goals of differentiated teaching. Teachers can differentiate instruction through differentiating content, activities, and product of students' learning in response to their interests and willingness to learn.

\section{Criteria for selecting online videos:}

Botirca (2007) mentions that when choosing online videos for use in classroom, certain general criteria should be considered:

1- watchability: selecting an interesting video to motivate students.

2- Completeness: The ideal video presents a complete story or a section of a story.

3- Appropriateness of content: It should be suitable to the age, culture and values of students.

4- Speech delivery: Clarity of speech, speech rate and accents are all factors in deciding how difficult a video is. 
5- Language content: When applying a video to present language, an important factor to consider is the linguistic items.

6- Language level: The language of the video should be suitable for the level of students.

7- Clarity of picture and sound: The video must be visually and orally clear.

\section{Related Studies:}

Yukselir \& Komur (2017) conducted a study that aims to improve the speaking abilities of EFL students at prep school by using online video at Osmaniye Korkut Ata. The study was conducted with 20 low level students in 5 classes. They were selected in accordance with the results of the first speaking exam that was administered 2015-2016. The materials used were five videos available online. These online videos were taken from Youtube, BBC, TED and VOA. Results showed that those who watched videos improved their speaking abilities.

Madzlan, Seng \& Kesevan (2020) conducted a study that aims to investigate whether public speaking anxiety can be alleviated through the use of online platforms and/ or video blogs. The creation of personal video blogs could potentially help learners by providing a safe and non-threatening learning environment in which to practise their public speaking skills. This study also aims to identify the factors that influence the use of video blogs as a public speaking platform. A mixed-method approach is designed to examine the effects of using video blogs. A set of questionnaires and semi-structured interviews were applied to groups of tertiary level ESL learners. Quantitative and qualitative approaches to data analysis were carried out and the results indicate that the use of video blogs does bring significant positive outcomes in reducing public speaking anxiety among ESL learners.

Yeh, Tseng \& Chen (2019) conducted a study that investigated the effects of online peer feedback via blogs on the speaking performance of college students studying English as a Foreign Language (EFL). Participants comprised 45 EFL college students,

Egyptian Journal of Educational Sciences (122) Issue 1 (Part One) 2021 
from two classes English Conversation and English Listening and Speaking, who were required to practice English speaking by recording a series of video clips and giving/receiving peer feedback on their speaking performance. Students also reflected on their experiences at the end of the semester. The collected data included the students' scores on their first and final video clips, their blog entries, and their self-reflection sheets. Based on the differences in scores on their first and final clips, the students were classified into groups who made more progress (MP) and less progress (LP) respectively. After receiving peer feedback through blogs, only the MP group showed significant progress in the development of the content of their videos, including introduction, supporting points and conclusions while both groups showed significant improvement in the delivery area except for vocabulary use and grammar.

Riyanto (2020) conducted a study that aims to investigate the benefits of integrating video making in a speaking class of the 29 first semester students of a public university in Surabaya, East Java Province, Indonesia. It employed action research which was done to improve the quality of the teaching and learning process of the class. The data were collected through direct observation in the classroom, video reviews, and survey. The findings showed that the integration of video making in a speaking class gave benefits to students in the form of four components i.e. social, language and literary, psychological, and technical. The class has been successful in integrating the video making in a speaking class which means that the integration may be applied again in the same class in the future or for a wider scope with similar conditions or settings.

Frisby et al. (2020) conducted a study that examined the use of virtual reality speaking rehearsals as one technology that instructors can adopt to enhance students' public speaking efficacy. Students $(\mathrm{N}=32)$ in this study practiced their final informative speeches in virtual reality 360-degree videos. They perceived their efficacy was enhanced in five ways including preparedness, realism, self-awareness, feedback, and comfort level. Conversely, efficacy inhibitors included the lack of presentational aids, technology

Egyptian Journal of Educational Sciences (123) Issue 1 (Part One) 2021 
issues, and lack of audience realism. The results are used to provide practical advice to instructors who would like to implement their own virtual reality rehearsal sessions.

\section{Research Questions:}

1- To what extent does the proposed online tours program enhance the EFL speaking skills of the secondary school students in the governmental language schools?

2- To what extent does the proposed authentic content-based program enhance positive atmosphere in the EFL speaking classes?

3- To what extent does the proposed online tours program enhance the fluency and accuracy of the secondary school students in the governmental language schools?

\section{Participants:}

The number of the experimental group was 26. The experimental group sample was an intact class from the first year secondary students in governmental language school in Tanta. The age of those students ranged from 14 to 15.

The participants studied English for nine years starting from the first year primary school. In the governmental language schools, students study two syllabi of English every year; an ordinary level (o-level) and an advanced level (A-level). The participants represented one experimental group which was taught the proposed online video tours program by the researcher in addition to their set English syllabus.

\section{Instruments:}

\section{The speaking test:}

The test consists of three parts: describing photos, narrating a sequence of actions and general speaking questions. The descriptive part required students to describe three photos and the narrative part asked students to narrate a sequence of specific occasions and events shown in a series of photos. The general 
questions were more abstract questions to which students should respond giving information and details about these general topics.

Students' responses were scored according to a rubric prepared by the researcher. The rubric was divided into two sections: fluency and accuracy. Fluency consists of three dimensions which are variety of style, the rate of speech and speech flow, whereas accuracy consists of grammar, vocabulary and pronunciation.

\section{Test validity:}

The test was submitted to jury members to judge the validity on basis of the clarity of photos, the level of difficulty and the suitability of the items for the subjects of the study. Some modifications were made based on the jury's suggestions.

\section{Test reliability :}

\section{Inter- rater reliability:}

The researcher rated students' responses to the speaking test, then asked a colleague, who works in a language school to rate students' speaking performance independently and following the same criteria mentioned in the speaking rubric. Correlation coefficients between the scores of both raters were calculated, and the table below illustrates the correlation coefficients.

Table (1)

The reliability of the speaking test

\begin{tabular}{|l|l|l|}
\hline Dimension & $\begin{array}{l}\text { Reliability } \\
\text { Coefficient }\end{array}$ & $\begin{array}{l}\text { Level of } \\
\text { Significance }\end{array}$ \\
\hline \hline Fluency & 0.91 & 0.01 \\
\hline Accuracy & 0.76 & 0.01 \\
\hline Total Test & 0.91 & 0.01 \\
\hline
\end{tabular}

As shown in the table, the reliability coefficients for all dimensions of the test are high. The levels of significance for the reliability of fluency, accuracy and total test are 0.01 . 


\section{The procedures:}

This research passed through the following procedures:

\section{Administering the pre- tests:}

The speaking pre-test and was administered as a pre- test to the experimental group before the applying the program.

\section{- The implementation of the program:}

The experimental treatment lasted for two months; two sessions every week. It took about 8 weeks. Each English session was 40 minutes. The experimental group was taught the proposed online tours program by the researcher.

During the first two weeks, the researcher gave an introduction about the program, its aim, its components and the procedures. The program was taught in the computer laboratory and the technology room. Then, the researcher started the program sessions which were given twice a week. The program consisted of six units, and each unit consisted of two sessions; each one included listening and speaking activities. The present program included varied communicative materials and activities that would serve the process of teaching and learning, motivate students and keep their attention. Videos are a good teaching resource for ESL/EFL students. Like all lessons, the program lessons should be planned and have a clear goal.

The students were asked for their agreement to take part in the experiment. All the students expressed their willingness to participate. The researcher informed them about the purpose of the study. They were told that a study would be carried out with the aim of developing their speaking skills and that they are going to travel to different parts of the world through videos and that will help them understand new listening material and acquire new vocabulary, and new information about a variety of countries.

The researcher applied collaborative learning strategy throughout the program since it is adequate for the communicative purpose of the program. This strategy is represented in the program activities like jigsaw activities, debates, oral presentations, and other

Egyptian Journal of Educational Sciences (126) Issue 1 (Part One) 2021 
group-work activities that were essentially based on students' interaction and collaboration.

\section{Post- tests:}

After teaching the proposed program to the experimental group, the researcher administered the speaking post-tests to the experimental group. The data obtained were statistically analyzed and interpreted to investigate the effectiveness of the program.

\section{The objectives of the program:}

The objectives of the program can be stated as follows:

1. Developing the speaking skills among secondary school students:

- To increase the students' flow of speech in oral production

- To pronounce words correctly.

- To use accurate grammar and a variety of vocabulary in speaking.

- To select words correctly

2- Giving students general information about different cities around the world.

4- Improving the positive and cheerful atmosphere in English classes.

\section{The content and the description of the program:}

The program includes six units consisting of six online tours and authentic videos that are based on the idea of tourism and travelling around the world, visiting the famous internationallyknown sights. The videos are relevant to students' language level, their experiences, and their culture. The videos were varied and up to date and included virtual field trips which took students to real natural environments. Each video is used through pre-viewing, during-viewing, post-viewing, follow-up, and home-assignment activities.

In the program, the researcher provided students with a variety of communicative and interactive activities and encouraging students to independently search for and organize 
content-related information. The selection of language content and activities has been done by the researcher in the light of:

1- Reviewing pupils' textbooks.

2- Objectives that were specified by the Ministry of Education.

3- Objectives of the program that were specified by the researcher.

4- The criteria for selecting videos from different sources.

\section{The content of the program:}

The selected videos provide students with a variety of trips to different cities in different countries. The Table below shows the six units included:

Table (2)

The content of the online tours program

\begin{tabular}{|c|c|}
\hline Program Units & City/Country \\
\hline \hline Unit One & Tokyo/Japan \\
\hline Unit Two & Paris/France \\
\hline Unit Three & Venice/Italy \\
\hline Unit Four & Seoul /Korea \\
\hline Unit Five & Barcelona/Spain \\
\hline Unit Six & Jordan \\
\hline
\end{tabular}

\section{The stages of teaching}

The first session of each unit was a listening and speaking session that followed the procedures of teaching these two skills. Farmer (2008) suggested that a well-structured lesson comprises the following five stages: warm up, pre-listening/viewing activities, during-listening/viewing, post-listening/viewing, and homework.

\section{1 - The warm- up:}

The researcher started the session by telling students about the city they are going to visit or the teacher can make students guess the city/country by giving information or asking questions or presenting pictures. The warm-up helped both the researcher to raise students' awareness of the topic (country/city) and activate their prior knowledge and language. The researcher began the lesson by pointing out what students already know instead of what they do not

Egyptian Journal of Educational Sciences (128) Issue 1 (Part One) 2021 
know to help establish positive atmosphere, confidence and selfassurance at the start of what may be a challenging topic for many students. The following activities were used:

- $\quad$ Discussion and brainstorming

Students discussed questions related to the city/country in groups.

\section{- $\quad$ Pictures}

Students described or discussed pictures that relate to the city/country in groups.

\section{2- The pre-viewing stage:}

Unlike the warm-up activities, the researcher here used activities that were directly related to the text and served to get students interested in the video, build confidence, and prepare them for the task ahead. Farmer (2008) stressed that it's common for teachers in lessons to carefully pre-teach the vocabulary. The researcher selected activities that help students get involved in the lesson.

These are activities that are directly related to the text, rather than the topic in general.

- Students predict the video and details: Students worked in groups, and shared ideas to the teacher.

- $\quad$ Presenting new vocabulary: In this activity, the researcher used photos to explain these words and encouraged students to say the definitions in English.

\section{3- The while- viewing stage}

These activities were intended to move students from extensive to more intensive tasks. Here, the students applied their deeper understanding. In this stage, the students were asked to give a brief summary of what they had watched in the video so far, what the main points were. The activities in this stage were:

- Language focus: Here, the researcher emphasized the structures and vocabulary that were used in the video. This is a chance to exploit the video for its language content. Authentic videos are often rich resources of vocabulary. All videos 
provide vocabulary related to the varied topics and also provide good structures and pronunciation aspects.

- Oral summary: Students were asked to give an oral summary of the topic covering the main points of the lesson.

- Vocabulary exercises: to test the students' comprehension of key vocabulary presented during the lesson. Students were asked to infer the meaning of unfamiliar words. The instructor distributed the exercise and gave students ten minutes to complete the questions.

\section{4- The post- viewing stage}

At this stage, the teacher checked students' detailed understanding of the video. The researcher used a variety of activities in this stage throughout the program lessons.

Students were performing or engaging in speaking activities. The teacher was listening and guiding the students; however, this was the time for students to demonstrate their speaking and language skills. The following activities were used throughout the program:

- Jigsaw activities: in these activities, different groups of students worked with different sections of the audio material then came together as a whole class to exchange information in order to cover the whole content.

- Retelling what has been heard: They can retell using their own words. This activity was a step prior to students' independence and their free oral practice. Students were divided into groups; each group retold the content presented in the video.

- Debate: It helped to let student express their views to develop effective speaking skills for students, which fostered their selfconfidence and the skill of persuasion.

- Role- play: The researcher used this activity because it is one of the motivating ways of encouraging students to speak. It is a way of bringing situations from real life into the classroom. Students pretend they are in various social contexts in the different countries they visited.

Egyptian Journal of Educational Sciences (130) Issue 1 (Part One) 2021 
- Oral presentation: Here, students worked in groups to prepare for an oral presentation based on the topic of the lesson. Students in each group cooperated and each student had a role such as note-taking, time-keeper, team leader, materials manager and in the program the whole group worked as presenters. Each student had a part of the presentation to deliver.

- Project work: Based on the country/city in the video or the documentary, students were encouraged to work on a project that represents their understanding, their basic concepts, and their additional work on the topic. Group work on projects was applied. Students designed posters illustrating the cities/countries. They produced various posters that differed in content and form.

- Home assignment: In this stage, the teacher gave students a link for another related video to watch at home to acquire more information on the same city/country. The researcher informed the students to watch the video to be discussed the next session and that information gained from the two videos should be presented in their oral presentations in the following speaking session.

\section{The Results:}

The t-test for paired samples was used to compare the pre- and post-scores of the experimental group on the speaking test. The SPSS (version 21) was used for analyzing the scores. 
The effectiveness of Online Virtual Tours in Developing EFL Speaking Skills among Secondary School Students

Table (3)

The " $t$ " values for the pre and post-test of the experimental group on the speaking test

\begin{tabular}{|c|c|c|c|c|c|c|c|}
\hline test & Group & $\mathbf{N}$ & mean & $\begin{array}{c}\text { Std. } \\
\text { Deviation }\end{array}$ & "tt" & df & Sig. \\
\hline \multirow{2}{*}{ Vocabulary } & Pre & 26 & 3.69 & 0.54 & \multirow[b]{2}{*}{9.66} & \multirow[b]{2}{*}{25} & \multirow[b]{2}{*}{0.01} \\
\hline & post & 26 & 4.81 & 0.40 & & & \\
\hline \multirow{2}{*}{ Pronunciation } & Pre & 26 & 3.15 & 0.61 & \multirow[b]{2}{*}{7.66} & \multirow[b]{2}{*}{25} & \multirow[b]{2}{*}{0.01} \\
\hline & post & 26 & 4.03 & 0.19 & & & \\
\hline \multirow{2}{*}{ Grammar } & Pre & 26 & 3.31 & 0.47 & \multirow[b]{2}{*}{11.35} & \multirow[b]{2}{*}{25} & \multirow[b]{2}{*}{0.01} \\
\hline & post & 26 & 4.38 & 0.49 & & & \\
\hline \multirow{2}{*}{$\begin{array}{c}\text { Total } \\
\text { Accuracy }\end{array}$} & Pre & 26 & 10.15 & 0.96 & \multirow[b]{2}{*}{16.06} & \multirow[b]{2}{*}{25} & \multirow[b]{2}{*}{0.01} \\
\hline & post & 26 & 13.23 & 0.58 & & & \\
\hline \multirow{2}{*}{ Fluency } & Pre & 26 & 10.19 & 1.23 & \multirow[b]{2}{*}{16.48} & \multirow[b]{2}{*}{25} & \multirow[b]{2}{*}{0.01} \\
\hline & post & 26 & 13.03 & 1.07 & & & \\
\hline \multirow{2}{*}{ Total score } & Pre & 26 & 20.34 & 1.89 & \multirow[b]{2}{*}{18.89} & \multirow[b]{2}{*}{25} & \multirow[b]{2}{*}{0.01} \\
\hline & post & 26 & 26.26 & 1.45 & & & \\
\hline
\end{tabular}

The table shows that there is a significant difference at 0.05 level between the mean scores of the experimental group students in the pre-and post-application of the total speaking test in favor of the post-application of the test.

As the results indicated, there are differences between the mean scores of the experimental group pupils in the pre-and postapplication of the speaking test in favor of the post-application of the test.

This progress may be due to the effectiveness of the suggested online tours program as a whole or each component separately (the activities, the videos, or the teaching method). In other words, the suggested program gave the students the 
opportunity to be more engaged in communicative activities, practice speaking through pair and group activities. Students were encouraged to give oral presentations in front of the whole class to promote their self-confidence and foster their self-esteem. They also took part in many group activities which were based on communication with each other and with the researcher such as presentations, role-plays and interviews.

\section{Accuracy:}

Students' performance improved in terms of (a) students' pronunciation, most of the students could pronounce words in a correct stress and intonation, and they could pronounce the sounds better. They could overcome most of the pronunciation problems detected in the pilot study and the pre-test; (b) Students' vocabulary, students learned many useful and practical vocabulary from the videos in the class; most of the students could apply the words correctly in conducting the different speaking activities; (c) students' grammar, most of the students could use the correct grammatical structures, word order and tenses. It was helpful for students to learn and practice the grammar with each other in the communicative context.

\section{Fluency:}

Most of the experimental group students could fluently perform the tasks. In addition, students could produce larger segments of speech without hesitations or pauses. They could communicate effectively with their peers and the teacher. The rate of speech got faster with fewer slowdowns. They showed flexibility in using language. Students could express their ideas precisely. Their use of fillers and false starts began to decrease.

Students were motivated and enthusiastic to speak in English and perform the speaking activities. They even showed their willingness to continue learning via online trips and they expressed their wishes that their traditional classes involved more communicative activities. The researcher gave students the needed feedback regarding the accuracy and the fluency of their oral

Egyptian Journal of Educational Sciences (133) Issue 1 (Part One) 2021 
language. During the program, the researcher emphasized specific pronunciation points such as stress and intonation. Students could realize how certain syllables are stressed in words and how words are stressed within the sentences. Students could also understand the rising and the falling intonation that was discussed during the program. This was manifested later in their speaking performance. Moreover, they could communicate effectively with each other with less need to use Arabic.

As the results showed, the proposed online tours program proved to be effective in promoting the speaking skill among students. In addition to developing the target skills, it helped them to deal with authentic materials to enhance the positive class atmosphere and expand their general knowledge.

\section{Recommendations:}

In the light of the study results, the following recommendations could be made:

-EFL teachers are recommended to use interactive and authentic activities while teaching speaking. Activities like oral presentations, role-play, projects, and discussions are more likely to involve students in a dynamic and interactive process.

-EFL teachers are recommended to use authentic videos and documentaries. Students find it engaging and challenging to watch documentaries related to different topics.

-EFL teachers and trainers are recommended to use the internet and technology in their English teaching to facilitate access to the authentic materials, saves time and effort, and helps to get students involved in the activities being performed. Moreover, it made the students more engaged in the activities.

-EFL teachers are recommended to use collaborative learning strategies especially in the speaking classes. This helps to improve students' self-confidence and create good relationships among students and between the students and their teacher. 


\section{References}

Al-Ghamdi, M. (2019) Virtual Reality in TEFL Context, Instructors' perspectives in a Saudi University. English Language and Literature Studies; Volume 9, No.2, 2019. Retrieved from http://www.ccsenet.org/journal/index.php/ells/article/view/0/39537 Alizadeh, M. (2019) Virtual Reality in the Language Classroom. Theory and Practice. Article in CALL-EJ- August 2019. Retrieved from https://www.researchgate.net/publication/335969992_Virtual_Rea lity in the Language Classroom Theory and Practice

Botirca, O.M. (2007) Teaching English with Video. Universitatea den Petesti. Retrieved from http://www.diacronia.ro/ro/indexing/details/A5588/pdf.

Celce- Murcia, M. (2001) Teaching English as A Second Language. United States. Heinle \& Heinle. Thomson Learning

Derakhshan, A.; Khalili, A. and Beheshti, F. (2016) Developing EFL Learner's Speaking Ability, Accuracy and Fluency. English Language and Literature Studies; Vol. 6, No. 2; 2016 ISSN 19254768 E-ISSN 1925-4776 Published by Canadian Center of Science and Education. Retrieved from http://www.ccsenet.org/journal/index.php/ells/article/viewFile/600 70/32159.

Frisby, B. ;Kaufmann, R.; Vallade, J. ;Frey, T. \& Martin, J.(2020) Using Virtual Reality for Speech Rehearsals: An Innovative Instructor Approach to Enhance Student Public Speaking Efficacy. Retrieved from https://eric.ed.gov/?q=using+videos+speaking+skills\&id=EJ1238854

Kasap (2005) The Effectiveness Of Task-Based Instruction In The Improvement Of Learners' Speaking Skills. Master's degree thesis The Institute of Economics and Social Sciences of Bilkent University. THE DEPARTMENT OF TEACHING ENGLISH AS A FOREIGN LANGUAGE BILKENT UNIVERSITY ANKARA. Retrieved from http://www.thesis.bilkent.edu.tr/0002848.pdf.

Madzlan, N.; Seng, G.; Kesevan, H. (2020) Use of Video Blogs in Alleviating Public Speaking Anxiety among ESL Learners. Retrieved from https://eric.ed.gov/?q=using+videos+speaking+skills\&id=EJ1250891 
Mead, Nancy A.; Rubin, Donald L.(1985). Assessing Listening and Speaking Skills. ERIC Digest. ED 263 626. Retrieved from https://eric.ed.gov/

Richards, Jack C. (2008) Teaching Listening and Speaking: From Theory To Practice. Retrieved from www. Professorjackrichards.com. Accessed 11-2-2016

Riyanto, E. (2020) The Benefits of Integrating Video Making in a Speaking Class. Retrieved from https://eric.ed.gov/?q=using+videos+speaking+skills\&id=EJ12658 $\underline{20}$

Rocio, Sigura Alonso ( 2011) The importance of teaching listening and speaking skills. MÁSTER EN FORMACIÓN DEL PROFESORADO DE EDUCACIÓN SECUNDARIA OBLIGATORIA, BACHILLERATO, FORMACIÓN PROFESIONAL Y ENSEÑANZAS DE IDIOMAS. Retrieved from https://www.ucm.es/data/cont/docs/119-2015-03-1712.RocioSeguraAlonso2013.pdf .

Watkins, J. \& Wilkins, M. (2011) Using Youtube in the EFL Classroom. Language Education in Asia, volume 2, Issue 1, 2011

Woolfitt, Z. (2015) The effective use of video in higher education. Inholland University of Applied Sciences. Retrieved from https://www.inholland.nl/media/10230/the-effective-use-of-videoin-higher-education-woolfitt-october-2015.pdf.

Yeh, H.; Tseng, S.; Chen, Y. (2019) Using Online Peer Feedback through Blogs to Promote Speaking Performance. Retrieved from https://eric.ed.gov/?q=using+videos+speaking+skills\&id=EJ12027 85

Yukeselir, C. \& Kumur, S. (2017) Using Online Videos To Improve Speaking Abilities of EFL Learners. European Journal of Education Studies. Volume 3, Issue 5. Retrieved from https://eric.ed.gov/?q=using+videos+speaking+skills\&id=ED579085 